\title{
EDYCJA DZIEŁA X. STANISŁAWA KŁOSSOWSKIEGO „CUDA Y LASKI... , I JEJ LOSY Z PERSPEKTYWY BIBLIOLOGICZNEJ
}

\begin{abstract}
Streszczenie
Kaliska księga cudów i łask doczekała się kilku edycji. Pierwsze wydanie ukazało się w 1780 roku. Księga była świadectwem żarliwej czci, jaką otaczał jej autor - ks. Stanisław Kłossowski - św. Józefa i miała służyć coraz szerszemu propagowaniu jego kultu. Autor interesującego nas dzieła sprawował swą kapłańską posługę w kolegiacie kaliskiej w latach 1751-1798. Artykuł stanowi próbę omówienia losów pierwotnej edycji dzieła ks. S. Kłossowskiego, kształtu fizycznego edycji oraz ewentualnych odmian, dziejów drukarni, z której wyszła książka, a także stanu zachowania w polskich bibliotekach. Asumpt do zainteresowania się księgą cudów dał reprint dzieła wydany w 2018 roku przez Wydawnictwo „Bernardinum” w Pelpinie, który został wykonany na podstawie egzemplarza przechowywanego obecnie w bibliotece kustosza kaliskiej kolegiaty.
\end{abstract}

Słowa kluczowe: Kalisz; stare druki; ks. Stanisław Kłossowski; Księga cudów; św. Józef; badania bibliologiczne

\section{Wprowadzenie}

Jakie były okoliczności i cel powstania księgi cudów? Czy można potwierdzić hipotezy o kilku wznowieniach? Co zawiera księga cudów? Jak przedstawia się postać fizyczna dzieła? Jaki jest stan zachowania księgi w bibliotekach polskich? Co kryją w sobie zachowane egzemplarze? Takie pytania nasuwają się bibliologowi w czasie lektury książki Cuda y łaski ks. Stanisława Kłossowskiego.

*Bogumiła Celer - dr nauk humanistycznych w zakresie bibliologii i informatologii; Kaliskie Towarzystwo Przyjaciół Nauk, Książnica Pedagogiczna im. A. Parczewskiego w Kaliszu; e-mail: b.celer@interia.pl

https://orcid.org/0000-0003-1617-5334 
Artykuł stanowi próbę omówienia losów pierwotnej edycji dzieła ks. S. Kłossowskiego, kształtu fizycznego edycji oraz ewentualnych odmian, dziejów drukarni, z której wyszła książka, a także stanu zachowania w polskich bibliotekach. Stare druki stanowią odrębny i specyficzny przedmiot zainteresowania badaczy i bibliotekarzy, są cenne ze względu na zawarte w nich treści, interesująca jest także ich postać materialna. Gromadzone w bibliotekach stanowią znakomity materiał źródłowy dla badaczy wielu dyscyplin. Wykorzystywane są również często jako eksponaty wystawiennicze czy też materiały ikonograficzne. Bibliotekarzom tego typu zbiory służą do badań bibliologicznych z dziedzin, takich jak: historyczne księgoznawstwo ${ }^{1}$, bibliografia, historia papiernictwa, drukarstwa, edytorstwa, ilustracji książkowej, opraw². Znaki proweniencyjne (znaki własnościowe, którymi opatrywano książki) i różnego typu zapiski są cenne dla historii bibliotek i czytelnictwa ${ }^{3}$.

Kaliska księga cudów i łask doczekała się kilku edycji. Pierwsze wydanie ukazało się w 1780 roku. Księga była świadectwem żarliwej czci, jaką otaczał ks. S. Kłossowski św. Józefa, miała służyć coraz szerszemu propagowaniu jego kultu. Autor interesującego nas dzieła sprawował swą kapłańską posługę w kolegiacie w latach 1751-17984, był znanym kaznodzieją, a dzięki jego staraniom obraz św. Rodziny został uznany za cudowny i koronowany w Kaliszu 15 maja 1796 roku. Oprócz księgi cudów - dzieła, które stawia go w szeregu kościelnych dziejopisów - ks. S. Kłossowski był autorem wydanej w 1778 roku książki Jezus Maryja Józef. Trojakie nabożeństwo do najświętszych Jezusa Maryi i Józefa... Źródła, do których dotarła Ewa Andrzejewska, podają, iż fundatorem tego dzieła był Ignacy Lipski, pochodzący z Lipego w Ziemi Kaliskiej, były dziedzic Błaszek, który zawdzięczał św. Józefowi uzdrowienie syna. Książka zawiera tę samą co księga cudów rycinę z cudownym wizerunkiem $\mathrm{z}$ kaliskiej kolegiaty.

${ }^{1}$ Por. M. Juda, Bibliologia historyczna w systemie nauk pomocniczych historii, w: Nauki pomocnicze historii. Teoria, metody badań, dydaktyka, red. A. Jaworska, R. Jop, Warszawa 2013 oraz T. Stolarczyk, Historia $w$ bibliologii. Rola badań historycznych $w$ odtwarzaniu dziejów bibliotek i księgozbiorów, http://dspace.uni.lodz.pl/xmlui/bitstream/handle/11089/30783/13-27_Historia\%20 w\%20bibliologii.pdf?sequence=1\&isAllowed=y (dostęp: 25.05.2019).

${ }^{2}$ Warto w tym miejscu wymienić literaturę poruszającą szczegółowe badania bibliologiczne: pismo i skład (H. Bułhak, Metoda typograficzna w badaniach nad dawna ksiażka. Uwagi i refleksje, „Biuletyn Poligraficzny”, (1977) nr 2, s. 37-52; M. Juda, Pismo drukowane w Polsce XVXVIII wieku, Lublin 2001), badanie elementów graficznych i ilustracji, czyli estetykę dawnej książki (M. Komza, Estetyka książi w badaniach bibliologicznych, w: Bibliologia i informatologia, red. D. Kuźmina, Warszawa 2011, s. 57-64; Z. Staniszewski, Estetyka polskiego druku książkowego XVIII w. Zarys problematyki, „Ze Skarbca Kultury”, 8 (1960) s. 126-164). Przy analizie karty tytułowej można wspomnieć o publikacji M. Judy, Karta tytułowa staropolskiej ksiązki drukowanej, „Odrodzenie i Reformacja w Polsce”, 46 (2002) s. 67-77.

${ }^{3}$ Por. M. Florianowicz, Zbiór starych druków w Bibliotece Wyższego Seminarium Duchownego w Koszalinie „Fides Biuletyn Bibliotek Kościelnych”, 21 (2015) nr 1 (40), s. 82. W przypadku badań proweniencyjnych można wymienić metody i badania odnoszące się do literatury ze zbiorów historycznych, bibliotek kościelnych zawartych w publikacji Ksiązka dawna i jej właściciele, zbiór studiów, red. D. Sidorowicz-Mulak, A. Franczyk-Cegły, t. 1-2, Wrocław 2017.

${ }^{4}$ E. Andrzejewska, Ks. Stanisław Józef Kłossowski (1726-1798). Kustosz Sanktuarium św. Józefa w Kaliszu, Kalisz 2010, s. 33. 


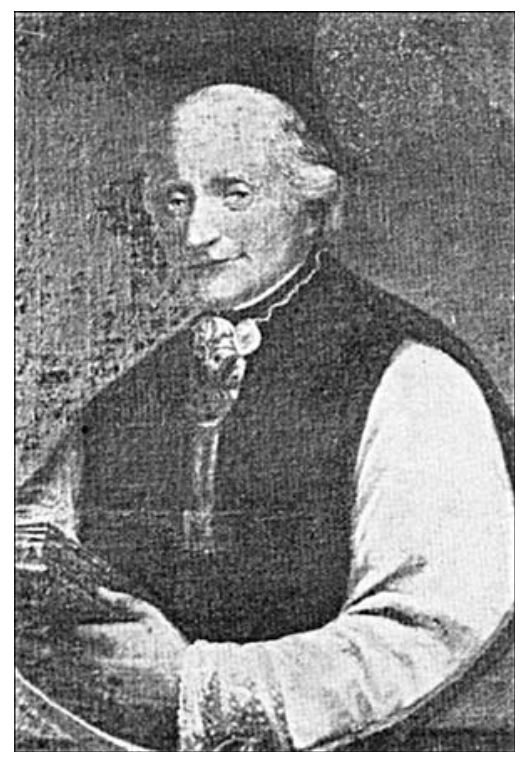

Il.1. Ks. Stanisław Kłossowski.

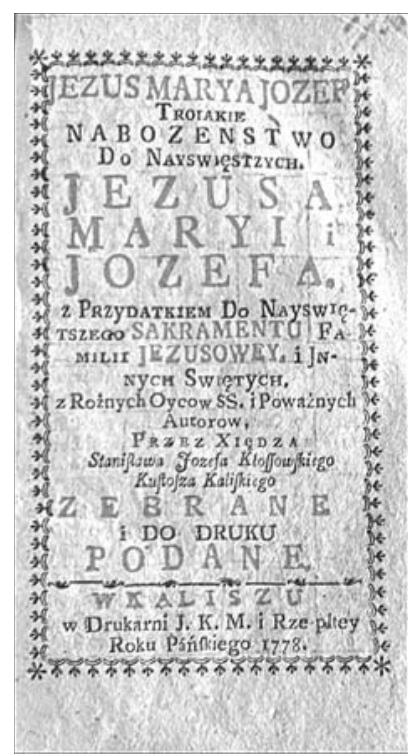

I1.2. Jezus Maryja Józef. Trojakie nabożeństwo do najświętszych Jezusa Maryi i Józefa..., Kalisz 1778. 


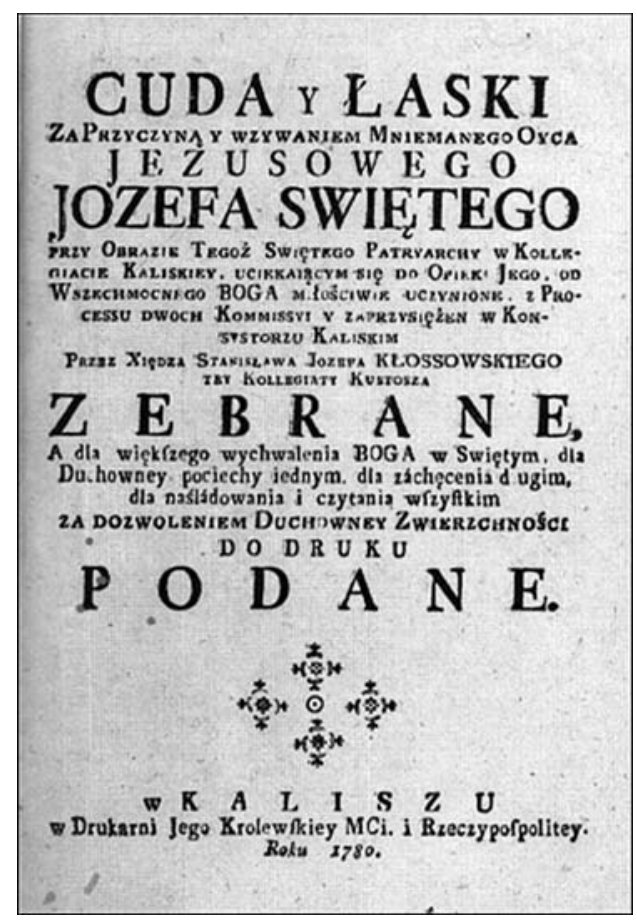

I1.3. Cuda y łaski za przyczyna y wzywaniem Mniemanego Oyca Jezusowego Józefa Świętego... ks. Stanisława Kłossowskiego, Kalisz 1780.

\section{Księga cudów na tle innych druków kaliskich z XVIII wieku}

Dzieło ks. S. Kłossowskiego reprezentuje typowy poziom rzemieślniczej produkcji książki w XVIII wieku. Wydając księgę cudów, kapłan skorzystał z usług kaliskiej drukarni Jego Królewskiej Mości i Rzeczypospolitej, dzierżawionej wówczas przez eks-jezuitę ks. Wiktora Wargawskiego. Oficyna miała bogate tradycje. $\mathrm{Na}$ opinię dobrego warsztatu drukarskiego zapracowali jej poprzedni właściciele.

W okresie Oświecenia Kalisz liczył ok. 4000 mieszkańców i był jednym z wielu średniej wielkości miast Rzeczypospolitej. Wyróżniał się jednak istniejącym od 1583 roku kolegium jezuickim oraz założoną w 1602 roku drukarnią, którą w latach 30. XVII wieku przejęło Towarzystwo Jezusowe5. Oficyna wywodziła się z warsztatu Jana Wolraba Młodszego. Działała nieprzerwanie przez 140 lat i wytłoczyła 930 druków. Na pomyślny rozwój drukarni wpłynęło niewątpliwie uzyskanie przez jezuitów w 1697 roku przywileju, na mocy którego oficyna otrzymała takie same prawa i ulgi, jakimi szczyciły się drukarnie królewskie. Od tego momentu wszyscy chcący drukować lub przedrukowywać książki wydane wcześniej w Kaliszu musieli zdobyć zgodę prowincjała zakonu. Nie bez znaczenia było również uzyskanie w 1744 roku prawa do tłoczenia podręczników na użytek

${ }^{5}$ A. Żbikowska-Migoń, Książka naukowa w produkcji typograficznej Kalisza w okresie Oświecenia, „Zeszyty Kaliskiego Towarzystwa Przyjaciół Nauk”, (2006) nr 9, s. 93-94. 
szkół w Prusach oraz Wielkopolsce. Jezuici uzyskali zgodę na edycję poprawionego wydania gramatyki Alvara oraz przywilej wyłączności druku w ciągu 20 lat słynnego słownika polsko-łacińskiego Grzegorza Knapskiego. Rozwój tłoczni pociągnął za sobą gruntowną modernizację jej wyposażenia polegającą m.in. na wymianie pras oraz materiału zecerskiego oraz stopniowe kształtowanie się doświadczonej kadry typografów ${ }^{6}$.

Po kasacie zakonu jezuitów w 1773 roku drukarnia będąca wówczas u szczytu swojej działalności stała się własnością Komisji Edukacji Narodowej. W kolejnym roku podjęto decyzję o wydzierżawieniu drukarni byłemu jezuicie ks. Wiktorowi Wargawskiemu, od tego czasu oficyna rozpoczęła działalność pod nazwą Drukarnia Jego Królewskiej Mości i Rzeczypospolitej. Postać ks. W. Wargawskiego jest dość interesująca. W literaturze znajdujemy informację, że były jezuita wywodził się z ziemi kaliskiej, urodził się w 1739 roku w podkaliskiej wsi Kuczewola (obecnie gm. Szczytniki). Studia filozoficzne ukończył w Krakowie, następnie przebywał w Poznaniu, ucząc syntaksy oraz retoryki. Ukończył także studia w zakresie teologii. Z kaliskim kolegium związany był w latach 1769-1771 jako słuchacz studium matematyki. Po rozwiązaniu zakonu w 1773 roku ponownie przyjechał do Kalisza i mimo iż nie miał żadnego przygotowania do prowadzenia drukarni, podjął się jej zarządzania. Wbrew pozorom zarządzał nią dość dobrze z pomocą Jana Markiewicza ${ }^{7}$. Spod pras tej pojezuickiej oficyny wyszło nieco ponad 100 tytułów, w większości polskojęzycznych (zważywszy na krótki okres działania drukarni jest to znaczący wynik $)^{8}$. Przyglądając się książkom, które opuściły kaliski warsztat, trzeba stwierdzić, iż Cuda y łaski ks. S. Kłossowskiego idealnie mieściły się $\mathrm{w}$ profilu wydawniczym drukarni. $\mathrm{W}$ repertuarze oficyny dominowała $\mathrm{w}$ dalszym ciągu książka religijna: kościelne druki urzędowe, homiletyka, piśmiennictwo dewocyjne (modlitewniki, katechizmy). Były to głównie duże zbiory egzort takich kaznodziejów, jak Adam Będkowski, Adam Cedrowicz, Wawrzyniec Rydzewski, Jerzy Trendel, Grzegorz Zacharasiewicz czy Karol Żułkiewski. Pojawiały się także książki naukowe, podręczniki, dysertacje teologiczne i filozoficzne, świeckie druki urzędowe, panegiryki, a nawet wydawane po raz pierwszy w Kaliszu - powieści. Wśród książek o charakterze naukowym i poznawczym W. Wargawski, korzystając ze wspomnianych wcześniej przywilejów, wytłoczył kolejne wydanie gramatyki Alvara oraz słownik jezuity Grzegorza Knapskiego.

Druki wychodzące spod prasy W. Wargawskiego, które miały wzorować się na XVIII-wiecznej książce francuskiej, były znacznie bardziej estetyczne niż te pochodzące z czasów jezuickich. Cechowały je m.in. format octavo, używanie czcionek antykwowych na kartach tytułowych oraz skromne zdobienia w formie finalików lub listewek złożonych z drobnych ornamentów drukarskich.

Warto także podkreślić, iż oficyna korzystała z możliwości informacyjno-reklamowych, co było rzadko spotykane w kaliskich drukarniach. W 1779 roku

${ }^{6}$ Por. K. Walczak, Drukarnie Kalisza. Zarys dziejów, Kalisz 1985.

${ }^{7}$ (1731-po 1793), dawnego prefekta oficyny jezuickiej oraz drukarza Tomasza Szurowskiego.

${ }^{8}$ J. Partyka, Calisiana w zasobie starodruków Biblioteki Jagiellońskiej, „Zeszyty Kaliskiego Towarzystwa Przyjaciół Nauk", (2016) nr 16, s. 87. 
W. Wargawski wydał katalog księgarski ${ }^{9}$, który liczył 176 pozycji. Oprócz informacji o książkach, które wyszły spod prasy drukarni, w katalogu znajdziemy także zapowiedź druku księgi cudów. Brak źródeł nie pozwala poznać pierwotnej ceny egzemplarza Cudów y lask.... Mimo iż informacje o kaliskich edycjach pojawiały się na łamach ówczesnych gazet, niestety księga cudów nie została odnotowana. Znajdujemy natomiast informację o innych kaliskich dziełach $\mathrm{z}$ tego okresu. Znane są kwoty płacone za książki w XVIII wieku, np. dwa tomiki książki drukowanej w oficynie pojezuickiej Ceremonie czyli Obrządki i zwyczaje, które bywaja $w$ kościele katolickim $w$ przypadajacych różnych okolicznościach zażywane $^{10}$ można było nabyć za $6 \mathrm{z}^{11}$. Natomiast za Kazania podczas czterdziestogodzinnego nabożeństwa ... w kolegiacie kaliskiej ${ }^{12}$, zbiór, w którym znajdują się także oracje ks. S. Kłossowskiego, trzeba było zapłacić $4 \mathrm{z}^{13}$.

Grupę twórców korzystających z usług kaliskiej oficyny stanowili mieszkańcy Kalisza i ziemi kaliskiej, dla których bliskość drukarni była atutem przy wyborze typografii. $Z$ tego też względu zapewne i ks. S. Kłossowski zlecił realizację swojego dzieła miejscowej oficynie. Zdarzały się także druki zlecone przez autorów niepowiązanych z Kaliszem. Jednym z nich był audytor sądu biskupiego w Krakowie Józef Olechowski, późniejszy biskup, którego Dokumenta do spraw dziesięcinnych $w$ Polszcze, wydane w 1779 roku w Krakowie, w tym samym roku przedrukowane zostały w Kaliszu ${ }^{14}$.

Ks. W. Wargawski prowadził drukarnię do listopada 1781 roku, kiedy w bliżej nieznanych okolicznościach umowa dzierżawy z księdzem została zerwana. Według badaczki Krystyny Bielskiej przyczynił się do tego prymas Antoni Ostrowski (1713-1784), który od jakiegoś czasu zabiegał o przeniesienie oficyny do Łowicza i połączenie jej z tamtejszą Drukarnią Prymasowską. Na mocy porozumienia zawartego w 1781 roku między Komisją Edukacji Narodowej a prymasem A. Ostrowskim, dobra pojezuickie, a tym samym i drukarnia, przeszły w ręce arcybiskupów gnieźnieńskich. Od tego momentu wydawnictwa ukazujące się w kaliskiej tłoczni sygnowano nazwą Drukarnia J.O. Xcia Jmci Prymasa Arcybiskupa Gnieźnieńskiego. Oficyna prowadzona przez wspomnianego już Jana Markiewicza kontynuowała swoją dotychczasową działalność z tą różnicą, że uzyskiwany dochód przekazywano na utrzymanie domu księży-emerytów w Łowiczu ${ }^{15}$. Nietypową publikacją w produkcji tłoczni był Diariusz podróży Ojca św. Piusa VI Papieża do Wiednia w roku 1782 odprawionej. Dzieło stanowiło dokumenta-

${ }^{9}$ Katalog ksiag w drukarni kaliskiey J.K.M. znayduiacych się, w Kaliszu: [Drukarnia J.K.M. i Rzeczypospolitej], 1779, https://polona.pl/item/katalog-ksiag-w-drukarni-kaliskiey-jkm-znayduiacych-sie,NjAzODA2MA/9/\#info:metadata (dostęp: 25.05.2019)

${ }^{10}$ Kalisz, 1780.

${ }^{11}$ „Gazeta Warszawska”, (1780) nr 60. Cyt. za S. Grzeszczuk, D. Hombek, Ksią̇ka polska w ogłoszeniach prasowych XVIII wieku. Źródła, red. Z. Goliński, t. 1, cz. 1: „, Gazeta Warszawska” 1774-1785, Wrocław 1992, s. 273.

${ }^{12}$ Kalisz, 1779.

${ }^{13}$ Grzeszczuk, Książka polska, s. 273-274.

${ }^{14}$ Por. Żbikowska-Migoń, Książka naukowa, s. 95.

${ }^{15}$ M. Sobczak-Waliś, Calisiana w kolekcji starodruków Miejskiej Biblioteki Publicznej im. Adama Asnyka w Kaliszu, „Zeszyty Kaliskiego Towarzystwa Przyjaciół Nauk”, (2016) nr 16, s. 161. 
cję bulwersującego wówczas opinię publiczną wydarzenia, jakim była papieska wizyta w stolicy Austriii ${ }^{16}$. Wyróżniało się na tle ówczesnych druków kaliskich staranną formą edytorską. Oficyna prymasowska działała do 1793 roku. Wraz z utratą niepodległości i przyłączeniem Kalisza do prowincji Prus Południowych drukarnia jezuicka opuściła miasto. Dalsze losy kaliskiego drukarstwa związane są z osobą Karola Wilhelma Mehwalda, który otrzymał od króla pruskiego tytuł „uprzywilejowanego drukarza królewskiego" i tłoczył w większości druki na potrzeby władz ${ }^{17}$.

Rok 1799 prawdopodobnie przyniósł wznowienie druku dzieła nieżyjącego wówczas od roku ks. S. Kłossowskiego. Badacze podają, że książka została opublikowana w kaliskiej drukarni Mehwalda. Karol Estreicher w Bibliografii Polskiej opierając się na informacji Bronisława Wojciechowskiego ${ }^{18}$, odnotował pod rokiem 1799 drugie wydanie księgi cudów. W relacji B. Wojciechowskiego zamieszczonej w opracowaniu z 1895 roku pt. Archiwum do dziejów literatury i oświaty w Polsce czytamy:

dzieło pt. „Cuda” miałem w ręku (dziś rzadkość bibliograficzna) i przytaczam tytuł w całości: „Cuda i łaski za przyczyną i używaniem mniemanego Ojca Jezusowego Józefa Świętego przy Obrazie tegoż Sw. Patryarchy w Kollegjacie Kaliskiej uciekającymi się do Opieki Jego od Wszechmocnego Boga miłosiernie uczynione przez W. Imci X. Stanisława Józefa Kłossowskiego tej Kollegjaty Kustosza zebrane R. P. 1799"19.

Opis bibliograficzny księgi pod nieco zmienionym i niedoprecyzowanym tytułem (Cuda y Łaski ś. Józefa milosiernie uczynione, przez W. Jmci X. Stanisława Józefa Kłossowskiego tey Kollegiaty Kustosza zebrane) zamieściła również pod rokiem 1799 Krystyna Bielska w Bibliografii starych druków kaliskich do końca VIII w. Badaczka jako miejsce przechowywania druku wskazała Bibliotekę Kórnicką. Przeprowadzona tam kwerenda niestety nie wyjaśniła kwestii prawdopodobnego wznowienia druku. W opisach katalogowych kórnickich egzemplarzy księgi widnieje data druku - 1780. Na jednej z kart katalogowych data zapisana jest w nawiasie kwadratowym, co oznacza, iż bibliotekarze nie są jej do końca pewni. Autopsja tego egzemplarza nie przynosi żadnych nowych ustaleń, gdyż księga nie posiada karty tytułowej i jest mocno zniszczona.

Istnieje również hipoteza o trzecim wydaniu księgi. W 2001 roku ks. Tadeusz Fitych w opracowaniu Na tropach świętego Józefa. Zestawienie polskiego piśmiennictwa z okresu XVII-XX wieku odnotował książkę pt. Św. Józef cudami stynący

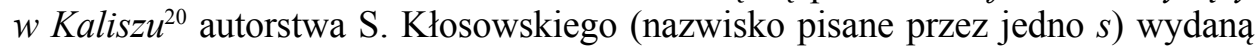

${ }^{16}$ Żbikowska-Migoń, Książa naukowa, s. 99.

${ }^{17}$ Walczak, Drukarnie Kalisza, s. 11.

${ }^{18}$ Bronisław Wojciechowski (1845-1902), lekarz, bibliotekarz Kaliskiego Towarzystwa Lekarskiego. Obok pracy zawodowej z zamiłowaniem oddawał się badaniu przeszłości narodu polskiego oraz studiom archeologicznym. Zob. Stownik biograficzny Wielkopolski poludniowo-wschodniej. Ziemi Kaliskiej, t. 1, red. H. Tadeusiewicz, Kalisz 1998, s. 295-296.

${ }^{19}$ B. Wojciechowski, Kronika szkół kaliskich z końca XVIII stulecia: praca oparta na źródłach archiwalnych gimnazjum kaliskiego, „Archiwum do Dziejów Literatury”, 8 (1895) s. 315.

${ }^{20}$ Por. Andrzejewska, Ks. Stanisław Józef Kłossowski, s. 42; K. Walczak, E. Andrysiak, D. Wańka, Druki kaliskie XIX i połowy XX w. (1800-1945), Kalisz 2003, poz. 429. 
w Kaliszu w 1870 roku. Ks. S. Kłossowski już nie żył, można więc przypuszczać, że wspomniana publikacja jest wznowieniem księgi cudów pod skróconym tytułem. Niestety, jak dotąd autorce nie udało się dotrzeć do druku, aby dokonać analizy komparatystycznej. Przypuszczalne kolejne wznowienie księgi cudów można wiązać z ogłoszeniem przez Piusa IX w 1870 roku św. Józefa patronem Kościoła katolickiego. Warto także odnotować, że w 1931 roku obszerne fragmenty dzieła zawierające najbardziej spektakularne opisy przypomniał w swej publikacji ${ }^{21}$ poświęconej św. Józefowi Kaliskiemu ks. Walery Pogorzelski (1870-1941).

\section{Zawartość, ksztalt fizyczny}

Pierwsze wydanie Cudów y lask liczyło 51 początkowych nienumerowanych kart, 548 stron numerowanych i końcowych 6 kart nienumerowanych. Księga prawie $\mathrm{w}$ całości napisana jest $\mathrm{w}$ języku polskim. Tylko kilkanaście stron zredagowanych zostało w języku łacińskim. Są to m.in. materiały z procesów dwóch kolejnych komisji badających cudowność obrazu. Początkowe nienumerowane karty stanowiące wprowadzenie do właściwej treści dzieła zajmują elementy tzw. literackiej ramy wydawniczej, będące nieodłącznym fragmentem starych druków ${ }^{22}$.

Karta pierwsza jest kartą tytułową z pełnym tytułem dzieła wraz z informacją o miejscu i roku wydania. Na kolejnych 10 kartach została zamieszczona prośba ks. S. Kłossowskiego do Trójcy Przenajświętszej, wyrażająca pełną pokory postawę autora. Następnie mamy Verba Sacre Scripture oraz przedmowy do czytelnika prawowiernego i niedowiarka. Kończąc przedmowę dla niedowiarka, ks. S. Kłossowski zapewniał, że „Łaski i Cuda (...) w tej księdze wiernie opisane (...) nie mają żadnych zdrad, ani matactw, ani żadnego zmyślenia”. Kolejne karty przynoszą aprobacje cenzorskie napisane w języku polskim, czyli zezwolenia władzy kościelnej na publikację dzieła. Informowały one, że dana książka wydrukowana została za zgodą odpowiednich władz i legitymuje się określonymi walorami. Aprobacje były także pewnym zaleceniem książki, rekomendowały ją. Dotyczyło to przede wszystkim książek o treści religijnej oraz dzieł, niezależnie od tematyki, wydanych w drukarniach zakonnych ${ }^{23}$. W przypadku księgi cudów zgodność treści z nauką Kościoła potwierdziły dwie osoby. Zgody na publikację zostały wydane 29 września 1779 roku przez Andrzeja Mroczyńskiego, profesora teologii oraz ks. Baltazara Poray Pstrokońskiego. Cały ten fragment książki zatytułowany jest „Censura \& Approbatio”. Konstrukcja aprobacji w Cudach y taskach jest podobna do zezwoleń cenzorskich obserwowanych w drukach staropolskich. Po określeniu „Approbatio”, zazwyczaj stanowiącym tytułowy element zapisu, zamieszczona jest zwięzła opinia o dziele ograniczona do stwierdzenia zgodności z zasadami wiary katolickiej i dobrymi obyczajami. Zapis zamyka formuła subskrypcyjna składająca się z imienia i nazwiska cenzora, jego tytułów naukowych

${ }^{21}$ W. Pogorzelski, Święty Józef w cudownym obrazie kolegiaty kaliskiej, Włocławek 1931.

${ }^{22}$ Por. P. Paluch, Dzieto Jacka Jabtońskiego o świętokrzyskim ośrodku kultu, „Teka Komisji Historycznej OL PAN", (2004) nr 1, s. 30.

${ }^{23}$ Tamże, s. 32; R. Ocieczek (red.), Dawne aprobacje cenzorskie - ich znaczenie dla badań dziejów ksiązki, w: Szkice o dawnej książce i literaturze, Katowice 1989, s. 101, 119. 
i zawodowych oraz daty wydania zezwolenia ${ }^{24}$. Literacką ramę wydawniczą dzieła zamykają napisane $\mathrm{w}$ języku łacińskim materiały $\mathrm{z}$ procesów komisji badających cudowność obrazu.

Właściwa część dzieła, czyli zebrane w księdze cudów relacje, pochodziły, jak wyjaśnił to sam autor, $\mathrm{z}$ dwóch źródeł. Pierwszym były materiały ze wspomnianych już procesów dwóch kolejnych komisji badających cudowność obrazu, powołanych przez metropolię gnieźnieńską. Drugim źródłem były zeznania złożone pod przysięgą przed przedstawicielami kaliskiego Konsystorza Foralnego. Relacje świadków zdarzeń uznanych za cuda lub łaski zostały w omawianym dziele ułożone w dwudziestu rozdziałach podzielonych na dwie księgi. Rozdziały uporządkowane zostały tematycznie i przedstawiają zdarzenia w układzie chronologicznym. Tytuły poszczególnych rozdziałów wskazują na sferę życia, w której odnotowana została ingerencja św. Józefa. Trzecia część księgi zawiera kazania, które podczas czterdziestogodzinnego nabożeństwa odprawianego w dniach od 10 do 12 września 1774 roku zostały wygłoszone przez kaznodziejów z Kalisza i okolic, m.in. przez ks. Andrzeja Cedrowicza, eks-jezuitę ks. Józefa Płochockiego, franciszkanina Idziego Mańkowskiego, paulina Arseniusza Lubińskiego, bernardyna Benedykta Łapińskiego, ks. Franciszka Chrzanowskiego i innych. Kazania uzupełniają opisy uroczystości związanych z czterdziestogodzinnym nabożeństwem, a także kilka cudów zgłoszonych w 1779 roku, już po wykonaniu składu części książki.

Księga cudów została wydrukowana w formacie $4^{\circ}$, quarto $(20 \times 25 \mathrm{~cm})$. W odróżnieniu od pierwszej książki autorstwa S. Kłossowskiego Jezus Maryja Józef, gdzie karta tytułowa posiada kompozycję tekstową z naprzemiennym drukiem w kolorze czerwonym i czarnym oraz z bordiurą typograficzną, na karcie tytułowej księgi cudów został zastosowany bardzo prosty układ - kompozycja tekstowa bez bordiury. Jedynym wyróżnieniem karty tytułowej Cudów y task jest niewielki akcent graficzny, tzw. ozdobnik, oddzielający tytuł dzieła od adresu drukarni. Strona tytułowa składa się z wierszy różnej długości, niektóre z nich są rozstrzelone. Rolę pewnego akcentu graficznego pełnią także różnej wielkości czcionki w tytulaturze. Styl ten stosowany był zwłaszcza w pierwszej połowie XVIII wieku, kiedy tytuły książek były długie, zajmując niejednokrotnie całą stronę druku. Dopiero pod koniec wieku zaczęła rozwijać się tendencja formowania skróconych tytułów. Treść księgi cudów została wydrukowana antykwą, użyto liter zarówno majuskulnych, jak i minuskulnych oraz kursywnych.

W księdze cudów wykorzystano skromny zasób ozdobników. Tych samych winiet używano kilka razy. Identyczne akcenty graficzne kaliska drukarnia stosowała w innych wydawanych tu drukach. Do zdobienia kart w książce posłużyły kompozycje przerywnikowe, polegające na podziale kolumny tekstowej wąskimi listewnikami ornamentu lub liniami przerywnikowymi. Ponadto poszczególne rozdziały zaczynają się ozdobnymi inicjałami, czasami ozdobionymi różnymi motywami. Spotykamy również ornamenty typograficzne i finaliki, czyli elementy zdobnicze, których obecność można tłumaczyć głównie dbałością o estetyczny wygląd księgi. Motyw taki, złożony zwykle z samych elementów dekoracyjnych,

\footnotetext{
${ }^{24}$ Paluch, Dzieło Jacka, s. 33; Ocieczek, Dawne aprobacje, s. 107, 110.
} 
służył do wypełnienia na karcie pustego miejsca po zakończeniu tekstu, dla ozdoby ${ }^{25}$. Oprócz paginacji na stronach występuje oznaczenie składek a2-e2, A-A2 aż do końca alfabetu. Po jego wyczerpaniu oznaczenia alfabetu podwajano, potrajano itd. ${ }^{26}$
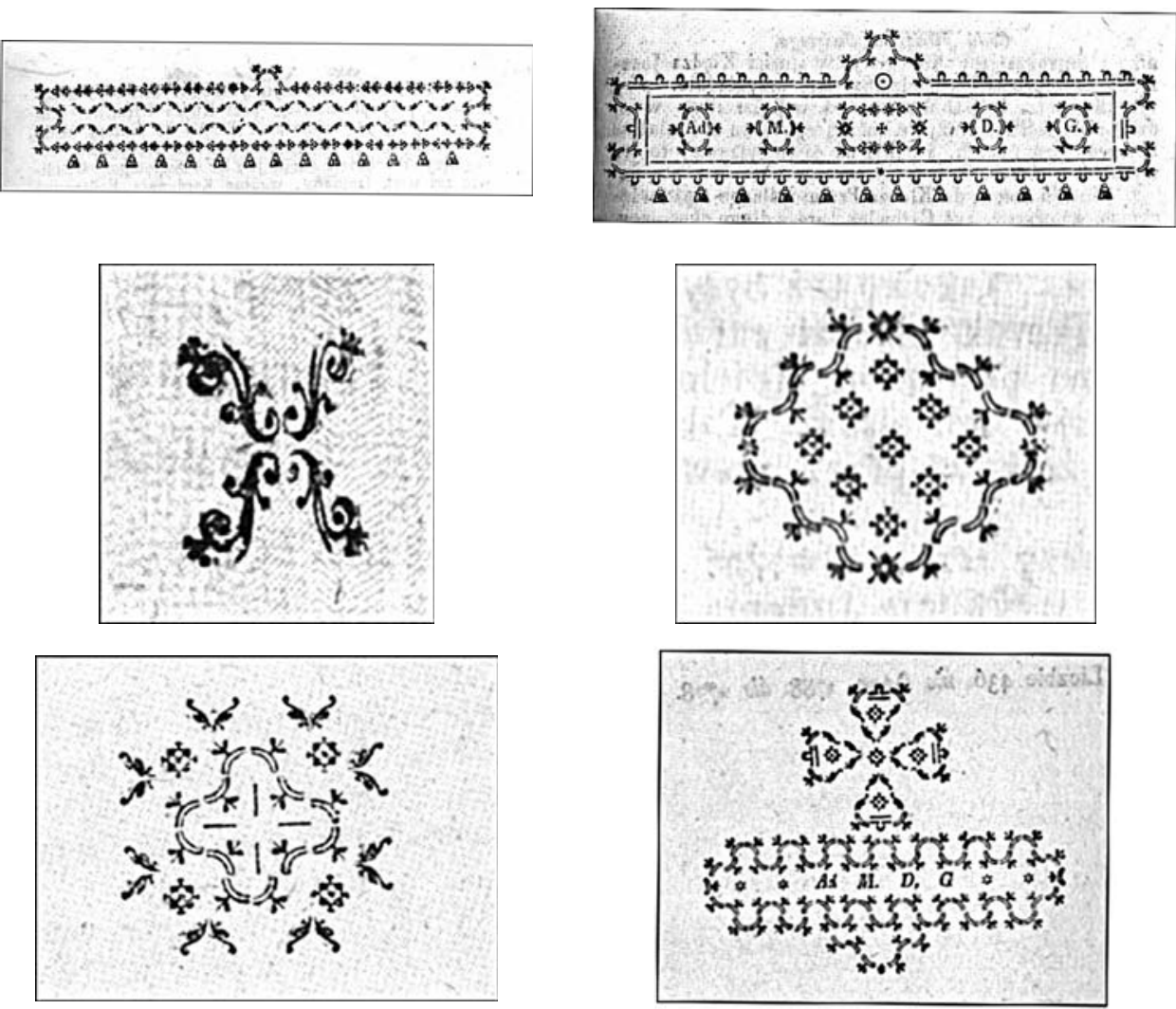

Il. 4-9 Ozdobniki i ornamenty typograficzne. Cuda y Laski, ks. S. Kłossowskiego, Kalisz 1780.

Papier użyty do druku księgi cudów nie ma żadnych cech szczególnych, na egzemplarzu przechowywanym w Bibliotece Jagiellońskiej widoczne są filigrany ${ }^{27}$, dzięki nim można podjąć próbę identyfikacji papierni lub introligatorni, z której korzystała drukarnia, zlecając oprawę.

Estreicher w Bibliografii Polskiej wzmiankuje, iż kartę tytułową dzieła poprzedza miedzioryt. Kaliska badaczka - E. Andrzejewska - podaje, że spośród

${ }^{25}$ Por. A. Gronek, Finalik w najstarszych drukach cyrylickich: manifestacja nowożytnej estetyki, „Latopisy Akademii Supraskiej”, 7 (2016) s. 137.

${ }^{26}$ Por. Typografia, układ i treść „,Korony Polskiej”, w: I.M. Dacka, Korona Polska „Kaspra Niesieckiego". Pomnik staropolskiego piśmiennictwa heraldyczego, Warszawa 2004, s. 32.

${ }^{27}$ Uwagi o wyglądzie dzieła uzyskano dzięki uprzejmości Beaty Kurek, pracownika działu zbiorów specjalnych BJ. 
nielicznych egzemplarzy tego „rara avis” tylko egzemplarze Biblioteki Uniwersyteckiej w Warszawie, Biblioteki Jagiellońskiej w Krakowie i Biblioteki Uniwersyteckiej KUL zachowały się z miedziorytem ${ }^{28}$. Po kwerendzie przeprowadzonej w polskich bibliotekach można uzupełnić tę informację. Jeden z dwóch egzemplarzy przechowywanych w Bibliotece Narodowej również zaopatrzony jest we wspomnianą kartę sztychową (czyli miedzioryt). Pozostałe stare druki bądź zostały pozbawione ryciny, bądź też ilustracje zostały puszczone w obieg w niewielu egzemplarzach. Niesygnowany miedzioryt, stanowiący rodzaj frontyspisu przedstawia kaliski cudowny wizerunek w srebrnych sukienkach, ze zdobiącymi ramę obrazu plakietami wotywnymi oraz wotami w postaci pary skrzyżowanych kul, stanowiących podpory dla chromych. Pod ilustracją znajduje się napis: Prawdziwe wyobrażenie Obrazu Świętego JOZEFA / Oblubieńca Nä̈s:[więtszey] MARYI Panny w Kościele / Kollegiaty Kaliskië̈ niezliczonemi codzeń / stynącego Cudy.

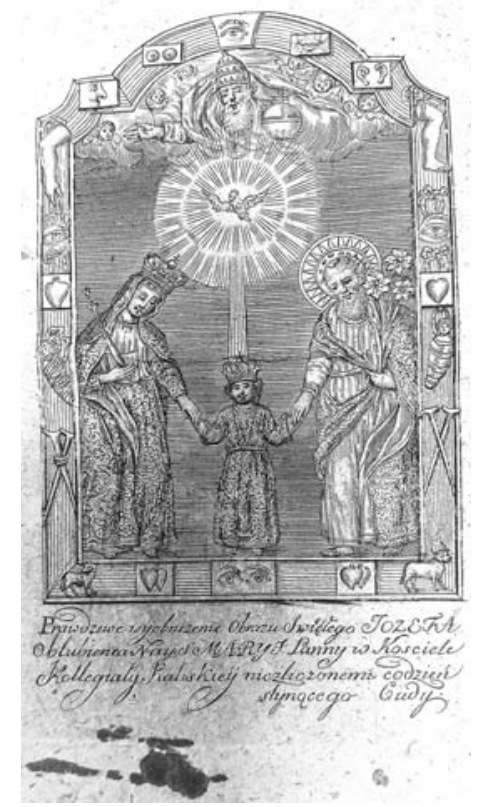

Il.10. Karta sztychowa, Cuda y Laski, ks. S. Kłossowskiego, Kalisz 1780. Miedzioryt zachowany w egzemplarzach z Biblioteki Uniwersyteckiej w Warszawie, Biblioteki Jagiellońskiej w Krakowie i Biblioteki Katolickiego Uniwersytetu Lubelskiego.

\section{Stan zachowania w polskich bibliotekach i księgozbiorach prywatnych}

Osiemnastowieczni bibliografowie książek rzadkich opracowali wielostopniową skalę rzadkości dzieła, przyjmując, że książki bardzo rzadkie to takie, których na świecie zachowało się nie więcej niż 50-60 egzemplarzy, podczas gdy książki najrzadsze występują co najwyżej w 10 egzemplarzach ${ }^{29}$. Księga cudów

${ }^{28}$ Andrzejewska, Ks. Stanisław Józef Kłossowski, s. 42.

${ }^{29}$ A. Żbikowska-Migoń, Druki gdańskie w XVIII-wiecznych bibliografiach książek rzadkich, „Libri Gedanenses. Rocznik Biblioteki Gdańskiej”, 50-51 (1999) s. 47. 
należy z pewnością do drugiej z wymienionych kategorii. Od czasu druku dzieła S. Kłossowskiego minęło ponad 200 lat i wiele egzemplarzy uległo zniszczeniu.

Ślady obecności Cudów y task w księgozbiorach prywatnych odnajdujemy, analizując treść ksiąg notarialnych. Ważnymi materiałami źródłowymi, przydatnymi do badań m.in. nad księgozbiorami domowymi, są inwentarze majątkowe sporządzane najczęściej przy okazji zapisów testamentowych, licytacji, sprzedaży ${ }^{30}$. Księga cudów figuruje w znanych dwóch zapisach inwentarzowych $\mathrm{z}$ akt notarialnych $^{31}$. Zapisy odnotowane zostały w aktach XIX-wiecznych notariuszy kaliskich: Józefa Godlewskiego i Andrzeja Bogusławskiego. Pierwszy akt przynosi nam informację, iż posiadaczem księgi cudów był ks. Antoni Józef Pogorzelski, kanonik łęczycki i uniejowski, oficjał i prepozyt w Krępie, proboszcz parafii w Kramsku (1793-1812). W testamencie zaznaczył „książki moje popodpisywane na licytacji przedać, i na ubogich, i na msze św. pieniądze rozdać”. $Z$, inwentarza pozostałości” spisanego w 1814 roku przez kolejnego notariusza wynika, że księga cudów znajdowała się również w księgozbiorze ks. Jana Nepomucena Widłaka, nauczyciela języka niemieckiego, fizyki i prawa w Kaliskiej Szkole Podwydziałowej.

Do dzisiaj - poza woluminem przechowywanym w kaliskiej kolegiacie - zachowało się zaledwie kilka zarówno kompletnych, jak i niepełnych egzemplarzy starego druku. W XVIII wieku nakład druków wahał się od 500 do 1500 sztuk $^{32}$. Niestety z powodu braku materiałów źródłowych nie jest znana pierwotna wysokość nakładu Cudów y łask. Egzemplarze dzieła S. Kłossowskiego odnaleźć można głównie w polskich bibliotekach uniwersyteckich i naukowych.

Bardzo pomocna, zwłaszcza w lokalizacji bibliotek posiadających interesujący nas stary druk, jest bibliografia Estreichera, w której jako miejsce przechowywania druku wskazana jest Biblioteka Jagiellońska i Biblioteka Zakładu Narodowego im. Ossolińskich ${ }^{33}$. Nieocenionym źródłem informacji dla badacza kaliskich starych druków jest Bibliografia starych druków do końca XVIII w. K. Bielskiej. Badaczka pisząc o kaliskiej księdze cudów, zaznacza jej obecność także w Bibliotece Narodowej (2 egzemplarze), Bibliotece Seminarium Metropolitarnego Archidiecezji Warszawskiej w Warszawie (4 egzemplarze) ${ }^{34}$, Bibliotece Uniwersyte-

\footnotetext{
${ }^{30} \mathrm{Na}$ przydatność akt notarialnych, a zwłaszcza ,inwentarzy pozostałości”, do badań nad księgozbiorami prywatnymi zwrócili uwagę w końcu lat 70. XX wieku: Halina Chamerska i Marian Lech. Zob. H. Chamerska, Akta hipoteczne i notarialne jako źródła do badań nad księgozbiorami prywatnymi XIX i XX w., w: Z badań nad polskimi księgozbiorami historycznym, red. B. Bieńkowska, z. 3, Warszawa 1977, s. 5-22; M.J. Lech, Akta notarialne jako źródła do badań nad księgozbiorami domowymi, „Studia o Książce”, 8 (1979) s. 187-200.

${ }^{31}$ Informacja Marcina Mikołajczyka, bibliotekarza Książnicy Pedagogicznej im. A Parczewskiego w Kaliszu, doktoranta Uniwersytetu Wrocławskiego.

${ }^{32}$ Por. Nakład, w: Encyklopedia wiedzy o ksiażce, red. A. Kawecka-Gryczowa, H. Więckowska, Wrocław 1971, kol. 1582; M. Czarnocka, Ilościowy rozwój polskiego ruchu wydawniczego 15021965, Warszawa 1967, s. 58.

${ }^{33}$ Zob. Elektroniczna Baza Bibliografii Estreichera (EBBE), https://www.estreicher.uj.edu.pl/staropolska/baza/wpis/?sort=id\&order=-1\&id=141240\&offset=101911\&index=13 (dostęp: 14.06.2019).

${ }^{34}$ 1. Sygn. H.3.11 (nr inw. 45333) oprawa zniszczona papier, półskórek, prow. na karcie przedtyt. Tekla Osiński. To jedyny egzemplarz który posiada kartę przedtytułową z ilustracją przedstawiającą kaliski wizerunek św. Józefa.; 2. Sygn. X.16.11 (nr inw. 65778) oprawa papier, półskórek, prow. bernardynów z Czerniakowa na wyklejce okładki i proweniencja nieczytelna na str. tyt. i trze-
} 
tu Warszawskiego ${ }^{35}$ (2 egzemplarze), Bibliotece PAN w Kórniku (2 egzemplarze) oraz w Bibliotece Poznańskiego Towarzystwa Przyjaciół Nauk.

Przeprowadzona kwerenda potwierdziła te informacje. Dzieło S. Kłossowskiego udało się także odszukać w katalogu starych druków Biblioteki Uniwersyteckiej KUL. Opis bibliograficzny dzieła został również zamieszczony w Bibliografii hagiografii staropolskiej ${ }^{36}$. Jej autorzy odnotowując Cuda y taski, jako proweniencję wskazują Bibliotekę KUL. Egzemplarz na tyle zwrócił zainteresowanie badaczy, że oprócz opisu zamieścili w bibliografii także reprodukcję karty tytułowej.

Zachował się także jeden egzemplarz w zbiorach prywatnych, w księgozbiorze prof. Krzysztofa Walczaka, który odziedziczył księgę po swoim ojcu, znanym kaliskim literacie Eligiuszu Kor-Walczaku.

\section{Oprawa}

Zachowane we wspomnianych bibliotekach egzemplarze księgi tylko w nielicznych przypadkach mają oprawę skórzaną ${ }^{37}$, najczęściej do oprawy stosowano jednak półskórek cielęcy brązowy, marmuryzowany. Na grzbiecie książki między wiązaniami zazwyczaj umieszczano malinowe szyldziki z tytułem. Oprawa była zdobiona tłoczeniami na ślepo lub złoceniami. Na jednym z egzemplarzy w Bibliotece Uniwersyteckiej w Warszawie oraz w Bibliotece Narodowej na grzbiecie znajdują się dwa szyldziki: malinowy i zielony, oraz malinowy i niebieski, a obcięcia kart barwione są na czerwono.

Na znanych nam woluminach największe piętno odcisnął czas, zniszczenia dotykały szczególnie opraw. Większość egzemplarzy ma uszkodzone grzbiety, naderwane okładziny górne, wytarte krawędzie okładzin, ślady po owadach. Niektóre tomy są zdefektowane, brakuje początkowych i końcowych stron. Szczególnie ciekawy (ze względu na stan zachowania) jest egzemplarz przechowywany w Poznańskim Towarzystwie Przyjaciół Nauk, który posiada ślady po kulach. Widoczne są od tyłu, ale nie doszły nawet do połowy grubości książki.

W Bibliotece Kórnickiej jeden z tomów (który prawdopodobnie został wydany w 1799 roku) posiada oprawę płócienną czerwoną z wytłoczonymi roślinnymi ozdobnikami oraz z czarnym szyldzikiem ze złoconymi literami na grzbiecie.

ci wpis na wyklejce tylnej okładki.; 3. Sygn. P.102.24 (nr inw. 111966) oprawa papier, półskórek, bez prow.; 4. Sygn. O.49.21 (nr inw. 75533) oprawa skórzana, bez prow. Informacje uzyskano dzięki uprzejmości Andrzeja Żebrowskiego z Biblioteki Wyższego Metropolitalnego Seminarium Duchownego w Warszawie.

${ }^{35}$ BUW od XIX wieku posiada dwa kompletne egzemplarze, w których tekst i rycina są dobrze zachowane. Niestety, w obu nie znajdujemy znaków własnościowych z XVIII wieku Uwagi o wyglądzie dzieła uzyskano dzięki uprzejmości Elżbiety Bylinowej, kustosza działu starych druków BUW.

${ }^{36}$ A. Witkowska, J. Nastalaska, Staropolskie piśmiennictwo hagiograficzne, t. 2: Bibliografia hagiografii staropolskiej, Lublin 2007, s. 74-75.

${ }^{37}$ Egzemplarz w UJ i jeden z egzemplarzy w BN. 


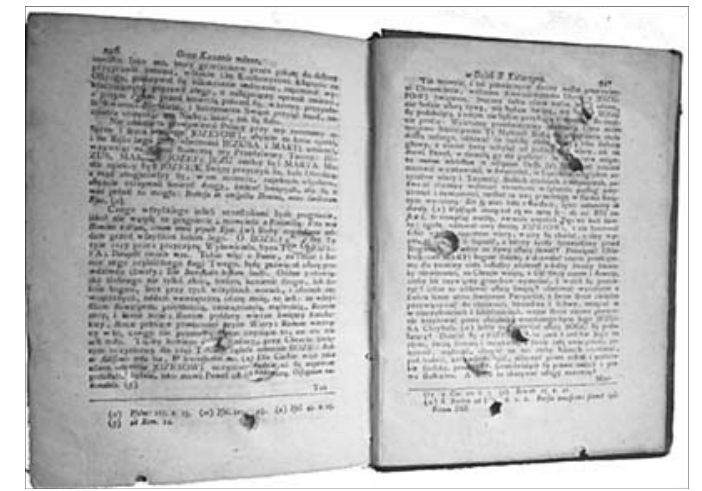

Il.11. Cuda y Łaski, ks. S. Kłossowskiego, Kalisz 1780.

Egzemplarz z Biblioteki PTPN

Specyficzny ze względu na oprawę jest także egzemplarz z księgozbioru prof. K. Walczaka. Księga oprawiona jest w półskórek i płótno, na przedniej okładce wytłoczony został krzyż, na tylnej kielich, grzbiet ozdobiony jest złoceniami. Nie zachowała się oryginalna strona tytułowa księgi, zastępuje ją karta $\mathrm{z}$ rękopiśmiennym zapisem tytułu. Na wewnętrznej stronie przedniej okładki znajduje się ekslibris obecnego właściciela. Przeglądając dokładnie egzemplarz, można dopatrzeć się także innych proweniencji. Na wewnętrznej stronie tylnej okładki w lewym górnym roku znajduje się trudny do zidentyfikowania odręczny zapisek: „Ks SZp.”. Można przypuszczać, że jest to adnotacja ówczesnego posiadacza książki, skrót „Ks” może wskazywać na księdza. Na ostatniej stronie na marginesie również znajduje się wpis, który można odczytać, jako: „W. Golczow?”. W tekście zachowały się ślady uważnej lektury, są to podkreślenia ołówkiem oraz czerwoną kredką, skreślenia, nanoszone przez czytelnika poprawki, krótkie adnotacje na marginesach. Przy jednym z fragmentów widnieje zapisek ,nie czytać”, który prowokuje do lektury tego fragmentu.

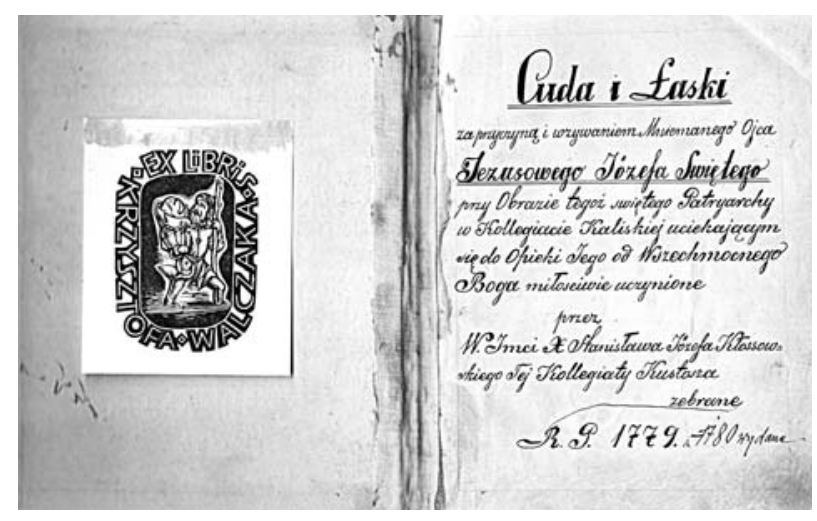

I1.12. Cuda y Laski, ks. S. Kłossowskiego, Kalisz 1780.

Egzemplarz z księgozbioru prof. K. Walczaka. 


\section{Proweniencje}

Bardzo ważnym źródłem wiedzy o dawnej książce, o jej historii od momentu opuszczenia drukarni, poprzez kolejnych posesorów, aż do miejsca, w którym przechowywana jest dzisiaj, stanowią proweniencje, czyli znaki własnościowe zamieszczane na książkach. Często kryją one w sobie pewne tajemnice, wskazując na zmianę właściciela i obrazując zadziwiającą wędrówkę książek. Są zwykle pomocne przy określaniu wykorzystania książek i księgozbiorów, zainteresowań czytelniczych użytkowników. Powtarzając za Krzysztofem Migoniem:

im częściej w książce lub przy książce możemy dostrzec człowieka, tym ciekawsze otwierają się perspektywy badawcze dla nauki o książce i tym większa jest poznawcza i praktyczna wartość wyników badań ${ }^{38}$.

Jednym z zadań bibliotekarzy katalogujących książki jest odnalezienie i wynotowanie znaków proweniencyjnych.

Przyglądając się zapiskom proweniencyjnym na zachowanych egzemplarzach dzieła ks. S. Kłossowskiego, można przypuszczać, iż księga cudów była dziełem czytanym i poszukiwanym. Znaki proweniencyjne na egzemplarzach to głównie krótkie zapisy własnościowe z nazwiskiem właściciela lub nazwą instytucji. Znajdujemy także zapiski rozbudowane (treściowe), ujawniające sposób nabycia książki, miejsce, datę - stanowią one tzw. znaki narracyjne. Poza tym występują również znaki biblioteczne: sygnatury, zapiski inwentarzowe, pieczątki ${ }^{39}$. W XVIII stuleciu, gdy biblioteki, także kościelne, znacznie rozbudowywały swoje księgozbiory, zmieniał się również sposób znakowania książek, pojawiły się pieczątki, ale nadal, przede wszystkim w bibliotekach klasztornych, preferowano odręczne, krótkie zapisy własnościowe informujące o bibliotece. W wiekach XIX i XX na kartach książek wzrosła liczba zapisów dedykacyjnych - dziękczynnych i grzecznościowych ${ }^{40}$. Nie wszystkie adnotacje są czytelne i łatwe do zidentyfikowania, jednak większość z nich daje możliwość rozpoznania osób i instytucji, które kiedyś miały księgę cudów w swoim posiadaniu.

Zapiski pierwszych XVIII-wiecznych dysponentów księgi cudów znajdują się na kilku egzemplarzach, m.in. na woluminie ossolińskim. Dzieło zawiera dwie rękopiśmienne proweniencje na karcie poprzedzającej kartę tytułową (tzw. wyklejce) Pierwsza o treści: „Ex libris Michaelis Lewicki Jarosłaviae d. 9 maii 1794". Adnotacja prawdopodobnie sporządzona została ręką wówczas 20-letniego Michała Lewickiego, późniejszego księdza katolickiego obrządku wschodniego, kardynała i greckokatolickiego prymasa Galicji i Lodomerii ${ }^{41}$. Na wyklejce

${ }^{38}$ K. Migoń, Nauka o książce wśród innych nauk społecznych, Wrocław 1976, s. 53.

${ }^{39}$ M. Pidłypczak-Majerowicz, Badania proweniencyjne $w$ bibliotekach kościelnych, „Fides. Biuletyn Bibliotek Kościelnych”, (2014) nr 1 (38), s. 4.

${ }^{40}$ Tamże, s. 10.

${ }^{41}$ Michał Lewicki ur. 16 VIII 1774 roku w Łanczynie na Pokuciu, zm. 15 I 1858 w Uniowie. Ukończył seminarium we Lwowie, świecenia kapłańskie przyjął w 1798 roku 20 września 1813 roku został biskupem przemyskim obrządku wschodniego, a 8 marca 1816 roku został podniesiony do rangi metropolity Lwowa, Halicza i Krzemieńca. W 1848 cesarz Franciszek Józef I nadał mu tytuł prymasa Galicji i Lodomerii. 16 czerwca 1856 został przez papieża Piusa IX mianowany kardynałem prezbiterem. Zob. J. Wołczański, Lewicki Rudolf, w: Encyklopedia katolicka, t. 10, red. E. Ziemann, Lublin 2004, kol. 896. 
widnieje drugi zapis: „Ta xąska Barbary Błaszewski kupiona roku 1812 Franciszek Ostroski”. Można zatem przypuszczać, że książką w pewnym okresie była własnością Barbary Błaszewskiej, a w 1812 roku została kupiona przez Franciszka Ostroskiego. W jaki sposób książka trafiła z biblioteki Michała Lewickiego do ich rąk, trudno dziś ustalić. Ossoliński egzemplarz zawiera też inne znaki własnościowe, pozwalające wskazać kolejne miejsca przechowywania dzieła. Obok adnotacji rękopiśmiennych znajduje się czarna owalna pieczęć „DUPLIKAT BIBLIOTEKI ORDYNACYI KRASIŃSKICH"42. Na stronie tytułowej umieszczona jest granatowa okrągła pieczęć z ok. 1870 roku „BIBLIOT. OSSOLIN.” związana z obecnym miejscem przechowywania. Zapisy proweniencyjne świadczą zatem o pochodzeniu starego druku z księgozbiorów prywatnych oraz o włączeniu go do Biblioteki Ordynacji Krasińskich, a następnie Biblioteki Zakładu Narodowego Ossolińskich.

Własnoręczne podpisy prywatnych właścicieli odnajdujemy również na egzemplarzach przechowywanych w Bibliotece Kórnickiej. Na karcie katalogowej jednego z woluminów odnotowano tylko jedną proweniencję o treści „Kawczyński B.” Autopsja księgi pozwoliła odkryć kolejny zapis, który wcześniej umknął bibliotekarzom katalogującym egzemplarz. Wynika z niego, iż książka należała także do Franciszki Dobrzyńskiej. Druk zawiera również dwie pieczęcie: okrągły odcisk pieczęci Biblioteki Kórnickiej PAN z herbem właścicieli Kórnika oraz odcisk owalny bez herbów.

Książka zachowana w Bibliotece Jagiellońskiej nie posiada wpisów własnościowych, jedynie na wewnętrznej stronie przedniej okładziny został wklejony ekslibris (odbitka czarna na białym tle), którym biblioteka posługiwała się od 1906 roku. Znak jest kompozycją otwartą zawierającą symbole Uniwersytetu Jagiellońskiego - dwa skrzyżowane berła pod koroną Kazimierza Wielkiego. W polu między berłami znajduje się monogram Biblioteki - BUJC. Na stronie tytułowej znajduje się pieczątka o treści: „Bibliotheca Univ. Jagiellonicae”.

Z Biblioteki Jagiellońskiej pochodzi także kolejny egzemplarz księgi cudów, przechowywany obecnie w zbiorach Biblioteki Narodowej. Świadczy o tym widniejący w księdze zapis o roku i sposobie nabycia dzieła do BN: „dar Biblioteki Jagiellońskiej z jej dubletów - 1946 r." Na zewnętrznej stronie tylnej wyklejki obok zapisów inwentarzowych znajduje się pieczątka: „Dublet Bib. Jag.” Drugi wolumin przechowywany w Bibliotece Narodowej trafił do tego księgozbioru w 1932 roku jako depozyt wieczysty z Biblioteki Wilanowskiej, mówi o tym m.in. notatka w inwentarzu o treści: ,przekazana w depozyt wieczysty Państwu Polskiemu z miejscem przechowywania w BN - 1932 r.”. Na egzemplarzu wid-

${ }^{42}$ Biblioteka powstała w 1844 roku. Zawiązkiem Bibliotek Krasińskich stały się zbiory Tomasza Czapskiego, starosty knyszyńskiego, które w kilkanaście lat po jego śmierci zostały wcielone do prywatnej biblioteki Wincentego Krasińskiego. Wniosła je w posagu Maria Urszula Radziwiłłówna, wnuczka Tomasza. W roku 1860, dwa lata po śmierci Wincentego Krasińskiego, w skład Biblioteki Ordynacji Krasińskich weszły ogromne zbiory, obejmujące książki, ryciny, rękopisy, obrazy, eksponaty archeologiczne i numizmaty, zebrane przez Konstantego Świdzińskiego. Zob. T. Dachtera, Konstanty Świdziński i jego zbiory: przyczynek do historii Biblioteki Ordynacji Krasińskich, „Biblioteka", (1997) nr 1 (10), s. 17-24. 
nieją dwie pieczątki. Pierwsza z przełomu XVIII i XIX wieku w kolorze czerwonym o treści: „Bibliotèque de Slubice”. Księgozbiór tej biblioteki zakupił dla Biblioteki Wilanowskiej hr. August Potocki w 1853 roku wraz z dobrami ziemskimi w Słubicach. Na stronie tytułowej znajduje się także czarna XIX-wieczna pieczęć Biblioteki Wilanowskiej. Ponadto na zewnętrznej stronie tylnej wyklejki w lewym górnym rogu znajdują się rękopiśmienne zapiski (rachunki), w prawym dolnym rogu notka o treści: ,Zap[isałem] [1]864 P[rzyłęcki]”. Wpis ręką bibliotekarza wilanowskiego Stanisława Przyłęckiego ${ }^{43}$ pozwala stwierdzić, iż pozycja wpisana została do katalogu biblioteki w 1864 roku, księgozbiór opieczętowany był w latach 1867-189244.

Równie interesujące pod względem proweniencyjnym egzemplarze księgi cudów zachowały się w Bibliotece Uniwersyteckiej w Warszawie. Widnieją na nich XIX-wieczne pieczątki następujących instytucji: Biblioteki Rządowej ${ }^{45}$, Biblioteki Sądu Apelacyjnego ${ }^{46}$ i Biblioteki Senackiej ${ }^{47}$.

Ciekawą notę proweniencyjną odnajdujemy na egzemplarzu z księgozbioru Biblioteki Poznańskiego Towarzystwa Przyjaciół Nauk ${ }^{48}$. Adnotacja ma charakter zapisu dedykacyjno-dziękczynnego. Przytoczmy ją ,in extenso”:

${ }^{43}$ Stanisław Przyłęcki (8 IX 1805 w Orzechówka na Witebszczyźnie - 1 VIII 1866 Wilanów) historyk, bibliotekarz, bibliograf. W 1832 roku został zatrudniony jako praktykant w tamtejszym Zakładzie Narodowym im. Ossolińskich. Po wykryciu w Zakładzie nielegalnych druków patriotycznych został na krótko jego nieformalnym kustoszem. Po przegraniu z Augustem Bielowskim konkursu na kustosza Ossolineum w 1845 roku pracował jako sekretarz w Galicyjskim Towarzystwie Gospodarczym. Kiedy jednak towarzystwo dotknęły kłopoty finansowe dzięki zabiegom Bielowskiego uzyskał 1 VIII 1862 posadę bibliotekarza zbiorów Augusta Potockiego w Wilanowie. Dziełem życia Przyłęckiego była dziesięciotomowa retrospektywna bibliografia piśmiennictwa pt. „Xsięgoznawstwo polskie powszechne” (obecnie w dziale rękopisów Ossolineum), efekt trzydziestoletnich poszukiwań w bibliotekach uniwersyteckich, klasztornych i magnackich Galicji i Królestwa Polskiego. Z pracy tej korzystał Karol Estreicher, pracując nad swą „Bibliografią polską”, choć określił ją jako „niekrytyczną zbieraninę”. Zob. Słownik Pracowników Książki Polskiej, red. I. Treichel, Warszawa-Łódź 1972, s. 727-728;

${ }^{44}$ Uwagi o wyglądzie dzieła uzyskano dzięki uprzejmości dr Bartłomieja Czarskiego - kierownika Zakładu Starych Druków Biblioteki Narodowej oraz pracownika działu - Krzysztofa Solińskiego.

${ }^{45}$ Biblioteka Rządowa (1834-1861) funkcjonowała w Pałacu Kazimierzowskim po zamknięciu i konfiskacie zbiorów Biblioteki Publicznej przy Królewskim Uniwersytecie Warszawskim. Zob. Katalog druków XV i XVI wieku w zbiorach Biblioteki Uniwersyteckiej w Warszawie, t. 8: Zbiorczy indeks proweniencyjny, red. M. Cubrzyńska-Leonarczyk, Warszawa 2018, s. 46-47.

${ }^{46}$ Biblioteka Sądu Apelacyjnego (1810-1841) założona w Warszawie przez Feliksa Łubieńskiego jako biblioteka publiczna, przekształcona w Bibliotekę Senacką. Zob. tamże.

${ }^{47}$ Biblioteka Senacka (1841-1862) powstała ze zbiorów Biblioteki Sądu Apelacyjnego po przejęciu jego kompetencji przez Departamenty IX i X rosyjskiego Rządzącego Senatu. Zbiory wcielone do Biblioteki Głównej w Warszawie - poprzedniczki BUW. Zob. tamże.

${ }^{48}$ Biblioteka PTPN gromadziła swój księgozbiór od założenia w 1857 roku początkowo wyłącznie drogą darów. Pierwsi członkowie Towarzystwa, a także inni przedstawiciele różnych środowisk społecznych, przekazywali zarówno pojedyncze egzemplarze druków czy manuskryptów pochodzące z rodzinnych zbiorów, jak i całe księgozbiory. Zob. J. Pietrowicz, Badania proweniencyjne księgozbiorów we wspótczesnej bibliotece. Na przykładzie Biblioteki Poznańskiego Towarzystwa Przyjaciół Nauk, „Kronika Wielkopolski”, (2016) nr 1 (157), s. 66. 
pamiątka śmierci jmci Księdza Cypryana radzikowskiego obchodzi się dnia 21 stycznia roku 1826 pamiątka śmierci jmci K[siędza] Kaietana Sypniewskiego obchodzi się dnia 23 grudnia roku 1833 ci byli moi oba dobrzy przyjaciele co do duszy iako duchowni bo K. K. S. ten mnie ochrzcił nauczył mnie religii iako pasterz dobry o iakiego teraz będzie trudno K. c. r. nauczył mnie czytać także pisać mogę Boga chwalić borze day im pokój wieczny. agata [Kwiatkowski].

Natomiast na wewnętrznych stronach tylnej i przedniej okładziny widnieje adnotacja: „ta książka jest własna agaty Kwiatkowski leśniczej Witoldowo[?]”. Dzieło posiada ponadto dodatkowe dwa inne znaki własnościowe. Na stronie tytułowej znajduje się autograf: „ks. W. Chrustowicz”, prawdopodobnie chodzi o ks. Wawrzyńca Chrustowicza, który w latach 1876-1886 w czasie kulturkampfu zarządzał parafią św. Wojciecha w Poznaniu jako administrator. Urodzony w 1841 roku, wyświęcony na kapłana w roku 1866 roku był mansjonarzem i pierwszym wikariuszem przy św. Wojciechu ${ }^{49}$. W roku 1886 został proboszczem w Miejskiej Górce. Egzemplarz zaopatrzony jest także w owalną zieloną pieczątkę: „Poznańskie Towarzystwo Przyjaciół Nauk".

Proweniencje odnajdujemy również na egzemplarzu z Biblioteki Uniwersyteckiej KUL, który opatrzony jest owalną pieczątką o treści: „Księgarnia Katolicka i Antykwarnia L. Bądkowski w Warszawie Święto-Krzyska 10"50 oraz rękopiśmiennym wpisem „Własność [nieczytelne, końcówka - „wskiego”] 1872 r.” Można przypuszczać, iż jest to zapis kapłana. Swoje księgozbiory przekazywali Bibliotece Uniwersyteckiej KUL kapłani wywodzący się ze środowiska włocławskiego, jej założyciel - ks. Idzi Radziszewski (1871-1923), księża profesorowie Antoni Szymański (1881-1942), Józef Kruszyński (1877-1953), Piotr Kremer (1878-1951), Cezary Pęcherski (1881-1925) oraz biskup lubelski Marian Fulman (1866-1945) $)^{51}$.

Reprint księgi cudów wydany w 2018 roku przez Wydawnictwo „Bernardinum" w Pelpinie został wykonany na podstawie egzemplarza przechowywanego obecnie w bibliotece kustosza kaliskiej kolegiaty. Wolumin posiada zapis rękopiśmienny, który nie został odwzorowany w reprincie. Na odwrocie karty tytułowej

${ }^{49}$ Chronologiczny spis proboszczów kościoła św. Wojciecha, http://www.swietywojciech.archpoznan.pl/historia/proboszczowie.html (dostęp: 26.06.2019).

${ }^{50}$ Ludwik Bądkowski h. Zagłoba (15 VII 1850 Łęczyca - 13 IV 1923 Warszawa) księgarz, antykwariusz. W Warszawie zamieszkał na stałe ok. 1880 roku. Od ok. 1905 roku. prowadził tam antykwarnię PF. Bądkowski Ludwik (ul. Świętokrzyska 10). Sprzedawał w niej podręczniki szkolne, beletrystykę oraz art. piśmiennicze. Zob. Stownik Pracowników Książi Polskiej. Suplement IV, red. M. Rzadkowolskiej, Warszawa 2016, s. 19.

${ }^{51}$ Księgozbiór bpa W. Owczarka w zbiorach BU KUL, http://www.bu.kul.pl/ksiegozbior-bp-w-owczarka-w-zbiorach-bu-kul,art_10881.html (dostęp: 26.06.2019). 
egzemplarza kaliskiego odnajdziemy adnotację: „Ex bibliotheka parafia Niemysłów"52. Jak niemysłowski egzemplarz trafił do Kalisza trudno dziś ustalićs3.

Dzięki wskazówkom E. Andrzejewskiej, można przypuszczać, że egzemplarz dzieła ks. S. Kłossowskiego mógł trafić do kaliskiej kolegiaty razem z kapłanem, który mógł być proboszczem w Niemysłowie, a zarazem kanonikiem w kaliskiej kolegiacie. Wydaje się to mało prawdopodobne, ale zdarzały się takie sytuacje. Przywołać można chociażby postać ks. Jana Nepomucena Trojanowskiego, który był proboszczem $\mathrm{w}$ dalekim Zagórowie, a zarazem prałatem w kaliskiej kolegiacie, albo ks. Ignacego Płoszaja (1842-1925), który był od 1889 roku dziekanem i proboszczem w Łasku, a zarazem kanonikiem kaliskim, i który przywiózł na kaliską wystawę organizowaną w 1900 roku kantatorium prymasa Łaskiego. Potem kantatorium to zostało w Kaliszu i dziś jest cennym eksponatem w Skarbcu ${ }^{54}$. Kalisz i Niemysłów w XIX wieku należały do rozległej diecezji kujawsko-kaliskiej. Po 1818 roku notujemy najwięcej przemieszczeń zabytków, np. ze zlikwidowanych kolegiat, skasowanych klasztorów (patena z Lądu „powędrowała” do Kalisza; monstrancja kartuzów w Gidlach do Kalisza - przechowywane są obecnie w Skarbcu Bazyliki). Możliwe, że starsze kaliskie egzemplarze Cudów y łask... zostały ,zaczytane” i nieznany kapłan mający związek z Niemysłowem uzupełnił ten brak. W Niemysłowie księga nie była pewnie potrzebna, a w Kaliszu jak najbardziej ${ }^{55}$.

\section{Zakończenie}

Stare księgi są jednym z najcenniejszych skarbów kultury materialnej. Biblioteki gromadzą stare druki jako wartość samą w sobie, jako świadectwo kultury ludzkiej i dziedzictwa narodowego. Przechowuje się je bez względu na treść, język, miejsce druku i formę piśmienniczą. Dawne książki mimo że wyszły niegdyś z jednej i tej samej oficyny wydawniczej, różnią się często oprawą czy też zna-

${ }^{52}$ Analiza akt wizytacji parafii z 1790 roku przechowywanych w Archiwum Diecezjalnym we Włocławku być może przyniesie informację, kiedy egzemplarz księgi cudów trafił do Niemysłowa. Ks. Wojciech Frątczak w swoim artykule podał jedynie, że: „Wizytator wylicza wszystkie księgi liturgiczne przechowywane w zakrystii, a także inne, z których na uwagę zasługują metryczne od 1605 r. i spis wszelkich dokumentów dotyczących własności kościelnej począwszy od „Liber benficiorum" Jana Łaskiego". Zob. W. Frątczak, Niemysłów w świetle wizytacji z 1790 roku, w: Sprawiedliwość, pokój i radość w posługiwaniu biskupim: księga pamiątkowa ku czci Jego Ekscelencji Księdza Biskupa dr. Wiesława Alojzego Meringa z okazji 65. rocznicy urodzin, red. A. Niemira, K. Rulka, J. Szymański, Włocławek 2010, s. 197-207.

${ }^{53}$ Niemysłów to parafia należąca obecnie administracyjnie do diecezji włocławskiej (dekanat uniejowski). Pierwsza historyczna wzmianka z 1262 roku świadczy, iż miejscowość ta była własnością biskupów gnieźnieńskich. Odtąd, aż do XIX wieku Niemysłów należał do dóbr arcybiskupów. Warto wspomnieć, iż w ołtarzu głównym Kościoła Świętego Michała Archanioła w Niemysłowie umieszczony jest barokowy obraz przedstawiający Świętą Rodzinę z Nazaretu, który jest wzorowany na obrazie św. Józefa z Kalisza. Na obrazie jest umieszczona metalowa sukienka w stylu rokokowym z 1725 roku. Obraz św. Rodziny w ołtarzu głównym jest zasłonięty obrazem św. Michała Archanioła.

${ }^{54}$ Por. E. Andrzejewska, Skarbiec Sanktuarium św. Józefa w Kaliszu (od lamusa do muzeum), „Rocznik Kaliski”, 41 (2015) s. 73.

${ }^{55}$ Informacja dr Ewy Andrzejewskiej. 
kami własnościowymi. Odtwarzanie proweniencji danego egzemplarza to jakby podjęcie próby rekonstrukcji książkowego życiorysu.

Dzieło ks. S. Kłossowskiego stanowi rodzaj piśmiennictwa hagiograficznego łączące treści związane $\mathrm{z}$ kultem oraz informacje historyczne. Zawarte w książce miracula są ciekawym i dość specyficznym źródłem informacji na temat życia $\mathrm{w}$ dawnym Kaliszu. $Z$ jednej strony współczesnego czytelnika może zniechęcać staropolszczyzna, czy też sam krój czcionek, być może „,pewna naiwność ujęcia"56, $\mathrm{z}$ drugiej jednak strony właśnie dlatego może okazać się to lekturą fascynującą.

\section{BIBLIOGRAFIA}

\section{Opracowania}

Andrzejewska Ewa, Ks. Stanisław Józef Kłossowski (1726-1798). Kustosz Sanktuarium św. Józefa w Kaliszu, Kalisz 2010.

Andrzejewska Ewa, Skarbiec Sanktuarium św. Józefa w Kaliszu (od lamusa do muzeum), „Rocznik Kaliski”, 41 (2015) s. 73-103.

Bułhak Henryk, Metoda typograficzna w badaniach nad dawna książka. Uwagi i refleksje, „Biuletyn Poligraficzny”, (1977) nr 2, s. 37-52.

Chamerska Halina, Akta hipoteczne i notarialne jako źródła do badań nad księgozbiorami prywatnymi XIX i XX w., w: Z badań nad polskimi księgozbiorami historycznym, red. B. Bieńkowska, z. 3, Warszawa 1977, s. 5-22.

Czarnocka Maria, Ilościowy rozwój polskiego ruchu wydawniczego 1502-1965, Warszawa 1967.

Dachtera Teresa, Konstanty Świdziński i jego zbiory: przyczynek do historii Biblioteki Ordynacji Krasińskich, „Biblioteka”, (1997) nr 1 (10), s. 17-24.

Dacka Iwona Monika, Korona Polska „,Kaspra Niesieckiego”. Pomnik staropolskiego piśmiennictwa heraldyczego, Warszawa 2004.

Encyklopedia katolicka, t. 10, red. E. Ziemann, Lublin 2004.

Encyklopedia wiedzy o książe, red. A. Kawecka-Gryczowa, H. Więckowska, Wrocław 1971.

Florianowicz Magdalena, Zbiór starych druków w Bibliotece Wyższego Seminarium Duchownego w Koszalinie, „Fides Biuletyn Bibliotek Kościelnych”, 21 (2015) nr 1 (40), s. 82.

Frątczak Wojciech, Niemystów w świetle wizytacji z 1790 roku, w: Sprawiedliwość, pokój i radość w postugiwaniu biskupim: ksiega pamiątkowa ku czci Jego Ekscelencji Księdza Biskupa dr. Wiestawa Alojzego Meringa z okazji 65. rocznicy urodzin, red. A. Niemira, K. Rulka, J. Szymański, Włocławek 2010, s. 197-207.

Gronek Agnieszka, Finalik w najstarszych drukach cyrylickich: manifestacja nowożytnej estetyki, „Latopisy Akademii Supraskiej”, 7 (2016) s. 137-148.

Grzeszczuk Stanisław, Hombek Danuta, Ksiązka polska w ogłoszeniach prasowych XVIII wieku. Źródła, red. Z. Goliński, t. 1, cz. 1, ,, Gazeta Warszawska” 1774-1785, Wroclaw 1992, 273-274.

Juda Maria, Bibliologia historyczna w systemie nauk pomocniczych historii, w: Nauki pomocnicze historii. Teoria, metody badań, dydaktyka, red. A. Jaworska, R. Jop, Warszawa 2013.

\footnotetext{
${ }^{56}$ Por. A. Tabaka, Miasto z cudami w tle, „Kalisia Nowa”, (2008) nr 8/9/10, s. 40.
} 
Juda Maria, Katalog druków XV i XVI wieku w zbiorach Biblioteki Uniwersyteckiej $w$ Warszawie, t. 8: Zbiorczy indeks proweniencyjny, red. M. Cubrzyńska-Leonarczyk, Warszawa 2018.

Juda Maria, Karta tytułowa staropolskiej książki drukowanej, „Odrodzenie i Reformacja w Polsce", 46 (2002) s. 67-77.

Juda Maria, Pismo drukowane w Polsce XV-XVIII wieku, Lublin 2001.

Komza Małgorzata, Estetyka książki w badaniach bibliologicznych, w: Bibliologia i informatologia, red. D. Kuźmina, Warszawa 2011, s. 57-64.

Książka dawna i jej właściciele, red. D. Sidorowicz-Mulak i A. Franczyk-Cegły, t. 1-2, Wrocław 2017.

Lech Marian, Akta notarialne jako źródła do badań nad księgozbiorami domowymi, „Studia o Książce", 8 (1979) s. 187-200.

Migoń Krzysztof, Nauka o książce wśród innych nauk społecznych, Wrocław 1976.

Ocieczek Renarda (red.), Dawne aprobacje cenzorskie - ich znaczenie dla badań dziejów ksiązki, w: Szkice o dawnej książe i literaturze, Katowice 1989, s. 101-122.

Paluch Piotr, Dzieło Jacka Jabłońskiego o świętokrzyskim ośrodku kultu, „Teka Komisji Historycznej OL PAN", (2004) nr 1, s. s. 23-48.

Partyka Jacek, Calisiana w zasobie starodruków Biblioteki Jagiellońskiej, „Zeszyty Kaliskiego Towarzystwa Przyjaciół Nauk", (2016) nr 16, s. 78-94.

Pidłypczak-Majerowicz Maria, Badania proweniencyjne $w$ bibliotekach kościelnych, „Fides Biuletyn Bibliotek Kościelnych”, (2014) nr 1 (38), s. 3-14.

Pietrowicz Joanna, Badania proweniencyjne księgozbiorów we współczesnej bibliotece. Na przykładzie Biblioteki Poznańskiego Towarzystwa Przyjaciót Nauk, „Kronika Wielkopolski”, (2016) nr 1 (157), s. 64-71.

Pogorzelski Walery, Święty Józef w cudownym obrazie kolegiaty kaliskiej, Włocławek 1931.

Słownik biograficzny Wielkopolski południowo-wschodniej. Ziemi Kaliskiej, t. 1, red. H. Tadeusiewicz, Kalisz 1998.

Słownik Pracowników Ksiązki Polskiej, red. I. Treichel, Warszawa-Łódź 1972.

Słownik Pracowników Książki Polskiej. Suplement IV, red. M. Rzadkowolska, Warszawa 2016.

Sobczak-Waliś Monika, Calisiana w kolekcji starodruków Miejskiej Biblioteki Publicznej im. Adama Asnyka w Kaliszu, „Zeszyty Kaliskiego Towarzystwa Przyjaciół Nauk”, (2016) nr 16, s. 157-189.

Staniszewski Zdzisław, Estetyka polskiego druku książkowego XVIII w. Zarys problematyki, „Ze Skarbca Kultury”, 8 (1960) s. 126-164.

Tabaka Anna, Miasto z cudami w tle, „Kalisia Nowa”, (2008) nr 8/9/10, s. 40.

Walczak Krzysztof, Andrysiak Ewa, Wańka Danuta, Druki kaliskie XIX i połowy XX w. (1800-1945), Kalisz 2003.

Witkowska Aleksandra, Nastalaska Joanna, Staropolskie piśmiennictwo hagiograficzne, t. 2: Bibliografii hagiografii staropolskiej, Lublin 2007.

Wojciechowski Bronisław, Kronika szkół kaliskich z końca XVIII stulecia: praca oparta na źródłach archiwalnych gimnazjum kaliskiego, „Archiwum do Dziejów Literatury”, 8 (1895) s. 315.

Żbikowska-Migoń Anna, Druki gdańskie w XVIII-wiecznych bibliografiach ksiażek rzadkich, „Libri Gedanenses. Rocznik Biblioteki Gdańskiej”, 50-51 (1999) s. 139-150.

Żbikowska-Migoń Anna, Książka naukowa w produkcji typograficznej Kalisza w okresie Oświecenia, „Zeszyty Kaliskiego Towarzystwa Przyjaciół Nauk”, (2006) nr 9, s. 93106. 


\title{
Netografia
}

Stolarczyk Tomasz, Historia w bibliologii. Rola badań historycznych w odtwarzaniu dziejów bibliotek i księgozbiorów, http://dspace.uni.lodz.pl/xmlui/bitstream/handle/11089/30783/13-27_Historia\%20w\%20bibliologii.pdf?sequence=1\&isAllowed $=\mathrm{y}$

\section{EDITION OF THE WORK BY REV. STANISLAW KLOSSOWSKI 'CUDA Y LASKI...’ AND ITS FATE FROM BIBLIOLOGICAL PERSPECTIVE}

\begin{abstract}
Summary
The Kalisz Book of Miracles has underwent several editions, the first of which was published in 1780 . The Book was a testimony to the fervent reverence that its author, Rev. Stanisław Kłossowski, held for St Joseph and was to serve the purpose of promoting his cult more widely. The author of the work in question exercised his priestly ministry in the Collegiate Church of Kalisz in the years 1751-1798. The article is an attempt to discuss the fate of the original edition of Rev. Kłossowski's work, the physical shape of the edition and possible variations, the history of the printing house the book was produced in, as well as the state of preservation in Polish libraries. The impulse to take an interest in the book of miracles originated from a reprint of the work published in 2018 by the Bernardinum Publishing House in Pelpin, which was carried out on the basis of a copy currently kept in the library of the Custodian of Kalisz Collegiate Church.
\end{abstract}

Keywords: Kalisz; old prints; Rev. Stanisław Kłossowski; the Book of Miracles; St Joseph; bibliological research 